\title{
Physiological and biochemical changes during the larval development of a brachyuran crab reared under constant conditions in the laboratory
}

\author{
K. Anger, J. Harms, C. Püschel \& B. Seeger \\ Biologische Anstalt Helgoland, Meeresstation; D-2192 Helgoland, Federal Republic of \\ Germany
}

\begin{abstract}
Larvae of the spider crab Hyas araneus were reared in the laboratory at constant conditions $\left(12{ }^{\circ} \mathrm{C} ; 32 \% \mathrm{~S}\right)$, and their feeding rate $(F)$, oxygen consumption $(R)$, nitrogen excretion $(U)$, and growth were measured in regular intervals of time during development from hatching to metamorphosis. Growth was measured as dry weight $(W)$, carbon $(C)$, nitrogen $(N)$, hydrogen $(H)$ protein, and lipid. All these physiological and biochemical traits revealed significant changes both from instar to instar and during individual larval moult cycles. Average $F$ was low in the zoea I, reached a maximum in the zoea II, and decreased again in the megalopa. In the zoeal instars, it showed a bell-shaped pattern, with a maximum in the middle (zoea I) or during the first half of the moult cycle (zoea II). Maximum $F$ in the megalopa was observed still earlier, during postmoult. Respiration $(R)$ increased in the zoeal instars as a linear function of time, whereas it showed a sinusoidal pattern in the megalopa. These findings on variation in $F$ and $R$ during larval development confirm results obtained in previous studies on $H$. araneus and other decapod species. Excretion $(U)$ was measured for the first time with a high temporal resolution in crab larvae. It showed in all three larval instars a bell-shaped variation pattern, with a maximum near the middle of the moult cycle, and significantly increasing average values from instar to instar. The atomic $O / N$ ratio followed an inverse pattern, suggesting a maximum utilization of protein as a metabolic substrate during intermoult. Growth data from the present study and from a number of previous studies were compiled, showing consistency of growth patterns, but a considerable degree of variability between larvae from different hatches reared under identical conditions. The data show the following consistent tendencies: during the first part of each larval moult cycle (in postmoult, partly in intermoult), lipids are accumulated at a higher rate than protein, whereas an inverse growth pattern is typical of the later (premoult) stages. These two different growth phases are interpreted as periods dominated by reserve accumulation in the hepatopancreas, and epidermal growth and reconstruction (morphogenesis), respectively. Differences between individual larval instars in average biochemical composition and growth patterns may be related to different strategies: the zoeal instars and the early megalopa are pelagic feeding stages, accumulating energy reserves (principally lipids) necessary for the completion of larval development, whereas the later (premoult) megalopa is a semibenthic settling stage that converts a significant part of this energy to epidermal protein. The megalopa shifts in behaviour and energy partitioning from intense feeding activity and body growth to habitat selection and morphogenesis, preparing itself for metamorphosis, i.e. it shows an increasing degree of lecithotrophy. Data from numerous parallel elemental and biochemical analyses are compiled to show quantitative relationships between $W, C, N, H$, lipid, and protein. These regressions may be used as empirical conversion equations for estimates of single chemical components in larval Hyas araneus, and, possibly, other decapods.
\end{abstract}




\section{INTRODUCTION}

In the past two decades, an increasing number of investigators studied developmental changes of physiological or biochemical traits in larval decapod crustaceans reared under constant environmental conditions in the laboratory. Most of these studies considered only one or a few isolated bioenergetic aspects such as larval food consumption, respiration, or growth rate (e.g. Emmerson, 1980; Paul \& Nunes, 1983; Dawirs \& Dietrich, 1986; Dawirs et al., 1986; Anger, 1987). In a few papers, more or less complete budgets were presented that described the uptake and partitioning of nutritional energy or materials (Mootz \& Epifanio, 1974; Logan \& Epifanio, 1978; Levine \& Sulkin, 1979 ${ }_{i}$ Johns, 1982; Dawirs, 1983). These investigations, however, had in general a low temporal (i.e. developmental) resolution and, thus, did not describe in detail bioenergetic changes during individual larval moulting cycles. A more comprehensive study (Sasaki et al., 1986) deals with changes in physiology and biochemistry during larval development, including changes during single moult cycles, in one of the best studied decapod models: the American lobster (Homarus americanus).

The present study attempts to combine comprehensiveness with a high temporal resolution, using one of the most suitable brachyuran model systems available for such studies, the spider crab Hyas araneus. Feeding, respiration, nitrogen excretion, and growth, the latter in terms of elemental (CHN) and proximate biochemical composition (protein, lipid) were studied, and results from investigations published in the past decade on this species were summarized. This review of older data will provide information on the degree of variation in larval growth rate and chemical composition, and the data are used to quantify relationships between single components of growth (e.g. dry weight and carbon, or nitrogen and protein). The present data set (mostly obtained from larvae originating from the same hatch) will be used as a basis for a simulation model, quantifying and illustrating patterns of change in energy partitioning during larval development, and it will allow the construction of complete budgets of carbon and nitrogen (in preparation).

\section{MATERIALS AND METHODS}

Hyas araneus L. larvae were obtained from ovigerous females collected near Helgoland (North Sea) and mass-reared in the laboratory at constant $12{ }^{\circ} \mathrm{C}$, ca $32 \% \mathrm{~S}$. Freshly hatched Artemia sp. (San Francisco Bay Brand ${ }^{\text {TM}}$ ) nauplii were given as food, and seawater and food were changed every second day (for details see Anger et al., 1983). The same standard conditions were used also in all physiological experiments (see below).

\section{Experiment A}

This experiment comprised simultaneous measurements (in larvae from the same hatch) of growth (dry weight, $W_{i}$ carbon, $C_{i}$ nitrogen, $N_{i}$ hydrogen, $H_{i}$ protein), respiration $(R)$, nitrogen excretion $(U)$, ecdysteroid levels, activity of digestive enzymes, and accumulation of age pigments (lipofuscin). The latter three aspects have already been published separately (Spindler \& Anger, 1986; Hirche \& Anger, 1987a, b). The $R, U$, and growth data from this experiment constitute the principal basis for budgets of energy, $C_{r}$ 
and $N$ (see above). Therefore, exclusively this experiment will be documented in some detail in the present paper, whereas results from the following ones serve as complementary information only, in particular on ingestion rates and biochemical composition of $H$. araneus larvae.

$W, C, N$, and $H$ were measured in regular intervals (20 time points during development), with 12 to 13 replicate samples. The samples were treated as described in detail by Anger \& Dawirs (1982) and Anger et al. (1983) and analysed, applying a Mettler UM3 microbalance and a Carlo Erba Science 1106 Elemental Analyzer. Energy content $(E)$ was estimated from $C$ (Salonen et al., 1976). This experiment comprised a total of 249 determinations of $W$ and $C H N$, with 465 individuals analysed.

Protein measurements ( 3 to 5 replicates) were carried out in parallel samples after Lowry et al. (1951) with bovine serum albumin (Serva 11930) as a standard.

Respiration was measured in closed bottles (ca $60 \mathrm{~cm}^{3}$ ) with a Winkler technique (Grasshoff, 1976) following the experimental design by Anger \& Jacobi (1985). Each respiration measurement comprised 8 replicate experiments (according to larval size, with 3 to 10 larvae in each bottle) and 4 replicate blanks (without larvae). The incubation time was ca $15 \mathrm{~h}$. Parallel to oxygen consumption, ammonia excretion was measured under identical conditions. The analytical procedure followed Solarzano (1969). Moult staging of the larvae was carried out using microscopical techniques (Anger, 1983) and the classification system proposed by Drach (1939).

\section{Experiment B}

The second experiment (larvae from another hatch) comprised simultaneous measurements of growth (as in Experiment A, but additionally with parallel lipid determinations) and ingestion rate. It comprised 22 sampling points during larval development, with 183 determinations of $W$ and $C H N$, and 429 larvae analysed. Total lipids were measured photometrically in 3 to 5 replicates with a Merckotest ${ }^{\circledast 2}$ reagent kit (Merck, Darmstadt), utilizing the sulfophosphovanillin reaction (Zöllner \& Kirsch, 1962).

Ingestion rates were determined daily in 20 individual larvae given freshly hatched Artemia sp. nauplii as food, following in general the procedures described by Anger \& Dietrich (1984). Quantitative image analysis, however, had to be replaced in the present study by a manual method: microscopical counting of the number of nauplii before and after a $24 \mathrm{~h}$ incubation period. In order to determine food biomass, brine shrimp nauplii were collected on Whatman (grade GF/C) glass fibre filters, immediately before and after an incubation period (10 replicates per measurement, with 200 nauplii in each) and analysed for $W, C, N$, and $H$. Average values (representing the middle of the incubation time) were taken as conversion factors to express ingestion rates in terms of $W, C H N$ or $E$. Since larval development and growth rates were similar to those in Experiment $A$, the ingestion rates measured in Experiment B were considered representative of Hyas araneus larvae and will therefore be used, together with growth, respiration, and excretion data from Experiment $A$, in the construction of complete budgets of energy and matter (see above). 


\section{Experiment $\mathrm{C}$}

Simultaneously measured growth data ( $W, C H N$, protein) from this experiment (conducted with larvae from a third hatch) are used in the present paper as a supplementary material. These growth measurements accompanied simultaneous investigations of nucleic acids (DNA, RNA) that will be published elsewhere (Hirche \& Anger, in prep.). In this experiment, $W$ and $C H N$ were measured at 24 sampling points, in 192 analyses with 400 larvae.

Besides the results of these three new experiments, original growth data ( $W, C H N$, in part also lipid and protein) from previous publications by our working group are used again in the present paper, in order to show variation among different hatches in Hyas araneus larvae, and to quantify relationships between these different measures of growth. Two of these previous papers (Anger \& Dawirs, 1982; Anger \& Jacobi, 1985) give, in different contexts, complete series of growth measurements conducted with high temporal resolution during the complete larval development of this species. Furthermore, chemical data were taken from the following studies: Anger et al. (1983), Kunisch \& Anger (1984), Hirche \& Anger (1987a), Hirche \& Anger (in prep).

\section{RESULTS}

\section{Feeding rate $(F)$}

Feeding rate (measured exclusively in Experiment B) varied greatly, not only between subsequent larval instars and during individual moult cycles (Fig. 1), but also from day to day and among replicate experiments (i.e. among 20 sibling larvae with identical age, treatment, etc.). Standard deviation of replicates (not shown in Fig. 1) usually amounted to \pm 10 to $20 \%$ of the mean values. In spite of high individual and daily variability, the high temporal resolution of the experiment (53 subsequent daily measurements) allows us to discern some clear trends. The overall level of $F$ was low in the zoea I, maximum in the beginning of the zoea II; then it showed a decreasing trend throughout the rest of larval development (Fig. 1a).

Feeding rates are given in Figure 1 in terms of numbers of Artemia nauplii consumed per day per larva. These figures can be converted easily to dry weight, carbon, nitrogen, or energy values, by multiplication with the average values given in Table 1 .

When variation of ingestion rate is considered separately in each larval moult cycle, distinct patterns may be recognized in subsequent instars. Maximum $F$ was found in the middle of the zoea I, during the first half of the zoea II, and in the beginning of the megalopa moult cycle, i.e. the maximum shifted during larval development from early premoult, through intermoult, and eventually to the postmoult stages (Figs 1b-d). The parabola shaped feeding curves in the zoea I instars can be described by quadratic polynomial equations:

$$
\mathrm{y}=\mathrm{y}_{0}+\mathrm{ax}-b \mathrm{x}^{2}
$$

$y$ is here $F_{;} x$ is time of development ( $t$ in days); $y_{0}$ (an estimate of the initial $y$ value), $a, b$ are fitted constants.

The variation pattern of feeding in the megalopa can be fitted better with an exponential type of equation:

$$
y=y_{0} e^{-a x}
$$



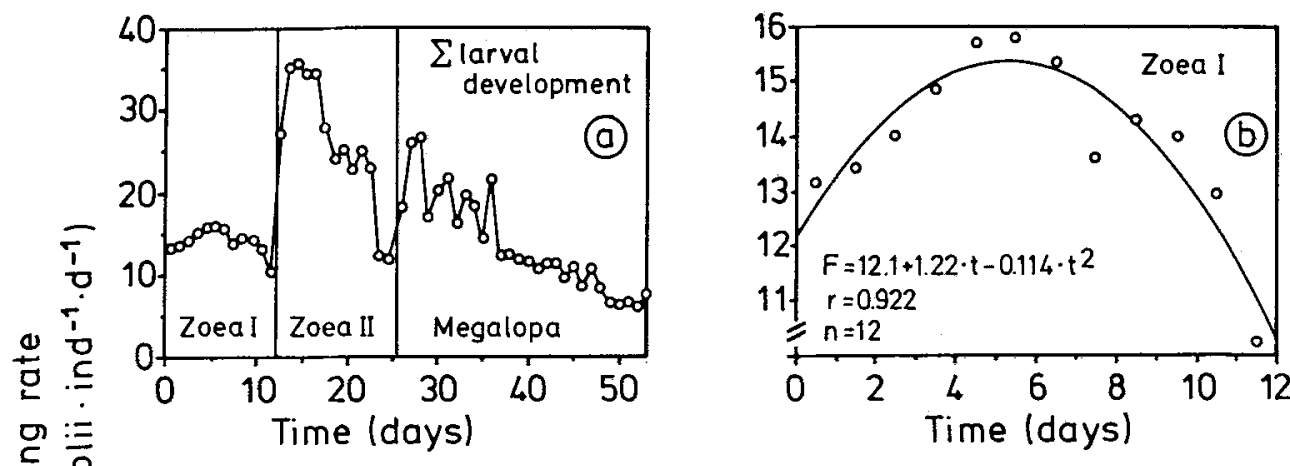

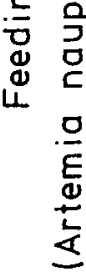
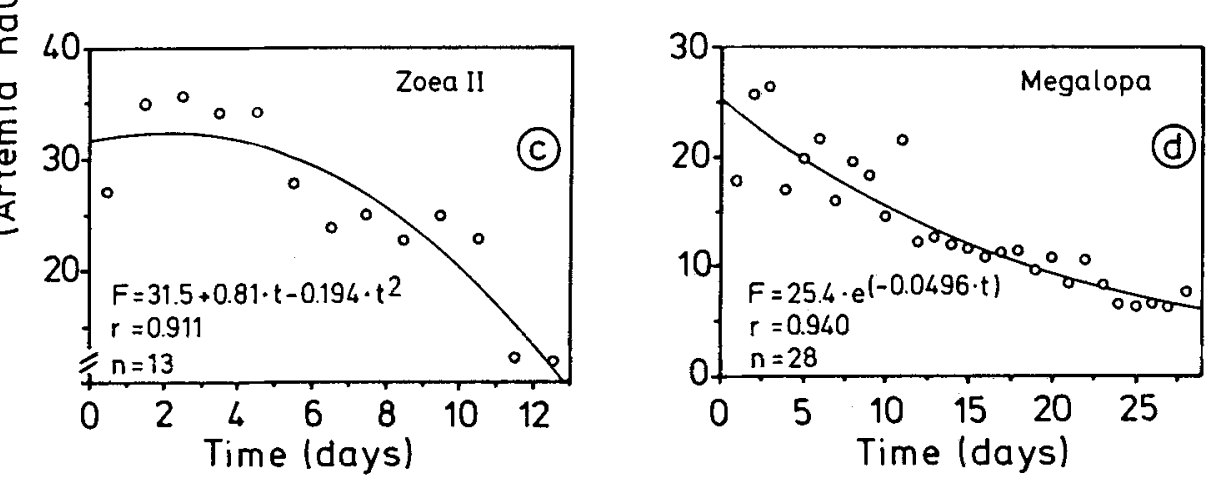

Fig. 1. Hyas araneus. Feeding rate ( $F$ : Artemia nauplii ind ${ }^{-1} \mathrm{~d}^{-1}$ ) during larval development. Regression equations: $F$ as a function of time ( $t$ : days) of development; $r=$ correlation coefficient; $n=$ number of subsequent experiments (mean values, from 20 replicates each)

Table 1. Artemia sp. Dry weight $(W)$, carbon $(C)$, nitrogen $(N)$ (all in $\mu g$ ind $^{-1}$ ), and energy content $(E$, in Joules ind $\left.{ }^{-1}\right)$, immediately after hatching and $24 \mathrm{~h}$ later; arithmetic mean $\pm \mathrm{SD}(\mathrm{n}=10)$. Average values were used as conversion factors for feeding rates of Hyas araneus larvae

\begin{tabular}{|lccc|}
\hline & Freshly hatched & $24 \mathrm{~h}$ old & Average \\
\hline$W(\mu \mathrm{g})$ & $1.65 \pm 0.23$ & $1.50 \pm 0.07$ & 1.57 \\
$C(\mu \mathrm{g})$ & $0.80 \pm 0.02$ & $0.74 \pm 0.02$ & 0.77 \\
$N(\mu \mathrm{g})$ & $0.14 \pm 0.01$ & $0.15 \pm 0.01$ & 0.14 \\
$E(\mathrm{~J})$ & $0.032 \pm 0.002$ & $0.030 \pm 0.001$ & 0.031 \\
\hline
\end{tabular}

The corresponding regression equations and correlation coefficients are given in Figs $1 \mathrm{~b}-\mathrm{d}$ and Table 3 .

\section{Respiration (R)}

The patterns of change in individual respiration (values: see Table 2) during larval development are depicted in Fig. 2. $R$ increased in both zoeal instars as a linear function of time:

$$
y=y_{o}+a x
$$




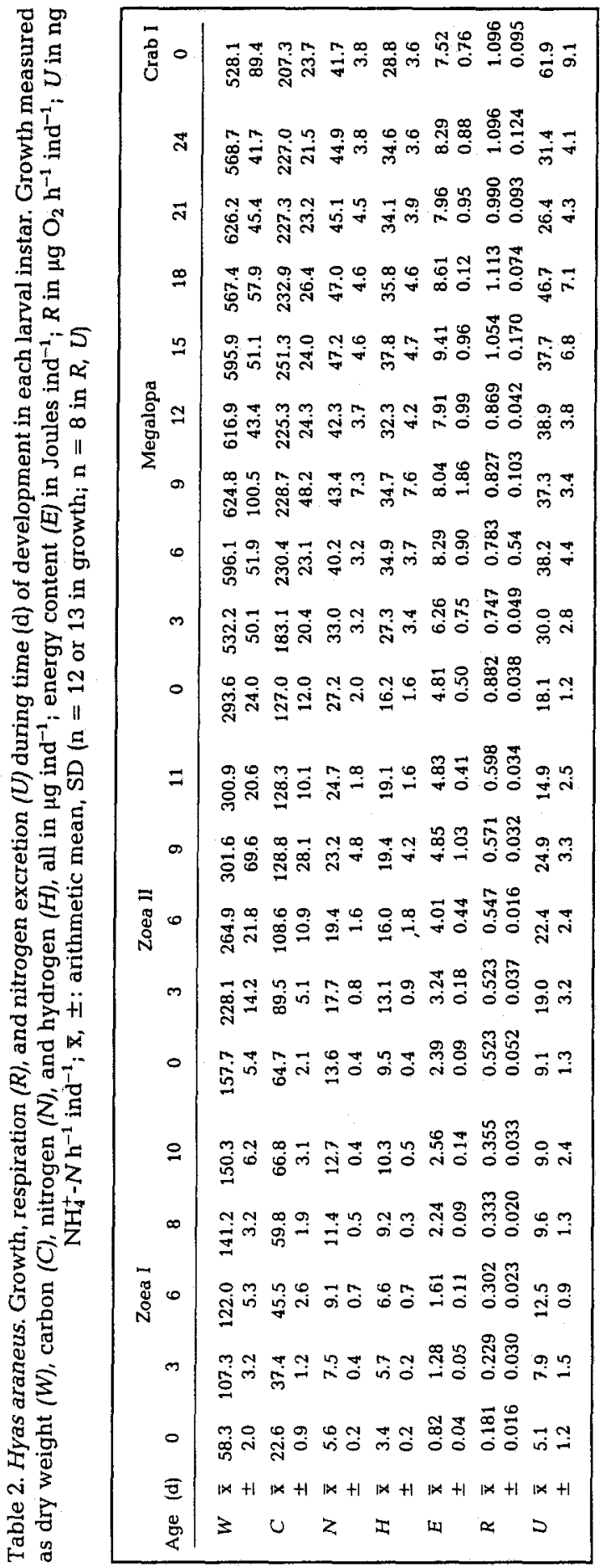


Time of development (days)

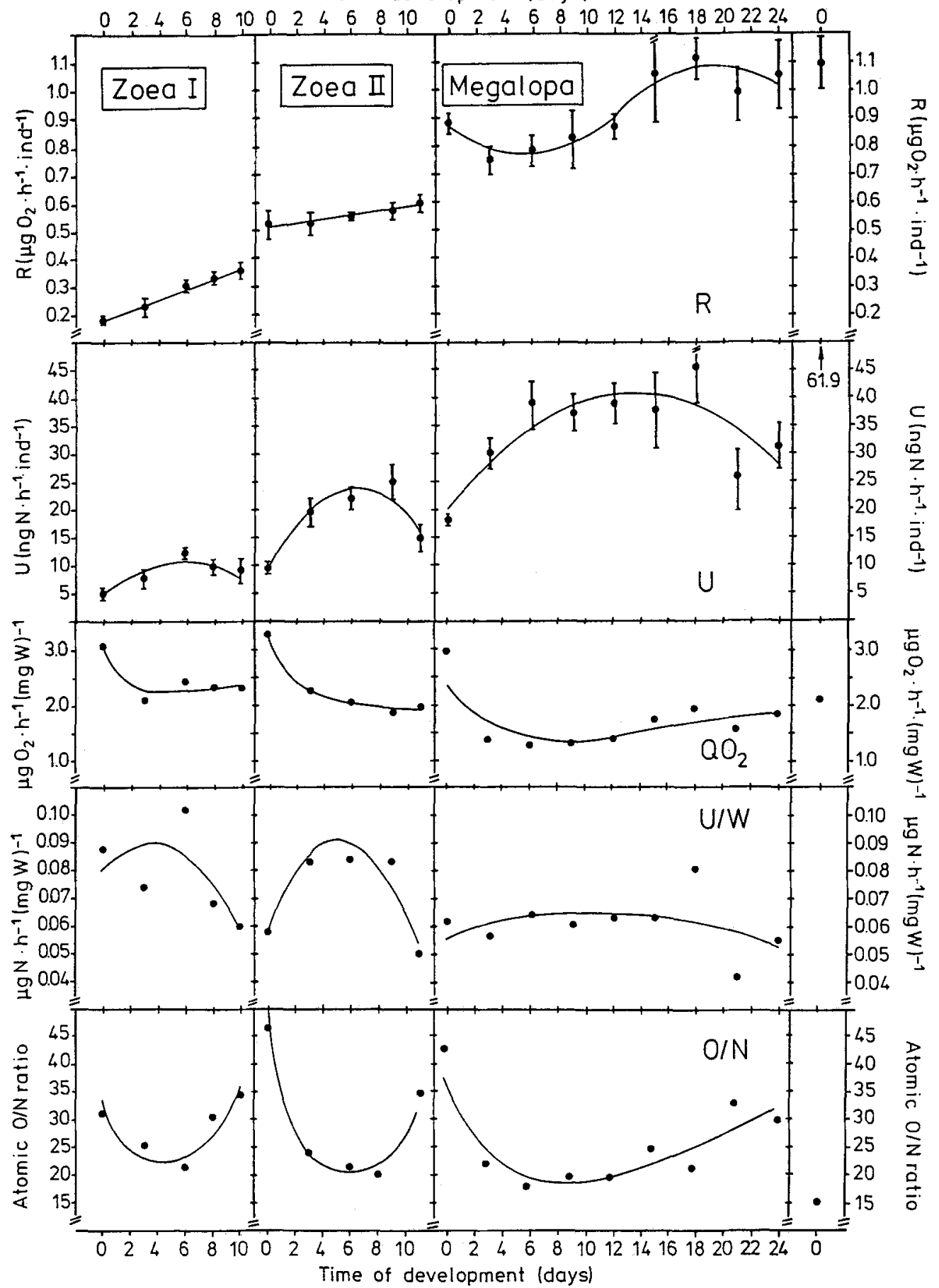

Fig. 2. Hyas araneus. Respiration ( $R$ : in $\mu \mathrm{g} \mathrm{O}_{2} \mathrm{~h}^{-1}$ ind $\left.{ }^{-1}\right)$, nitrogen excretion ( $U$ : in $\mathrm{ng} \mathrm{NH}_{4}^{+}-\mathrm{Nh}^{-1}$ ind $\left.^{-1}\right)$, weight-specific metabolic rate $\left(Q_{2}\right.$ : in $\mu \mathrm{g} \mathrm{O}_{2} \mathrm{~h}^{-1} \mathrm{mg} \mathrm{W}$ ), weight-specific excretion rate (U/ $W:$ in $\mu g \mathrm{NH}_{4}^{+}-\mathrm{N} \mathrm{h}^{-1} \mathrm{mg} \mathrm{W}$, and atomic $\mathrm{O} / \mathrm{N}$ ratio during the course of larval development. For regression equations see Table 3 and text 
$y$ is here $R$ (in $\mu \mathrm{g} \mathrm{O}_{2} \mathrm{~h}^{-1}$ individual ${ }^{-1}$ ), $x$ is time ( $t$ in days), and $y_{0}$ and $a$ are fitted constants (cf. Eq. 1).

In the megalopa instar, $R$ revealed a sinusoidal pattern that can be described best by a third order polynomial equation:

$$
\mathrm{Y}=\mathrm{yo}_{0}-a \mathrm{x}+b \mathrm{x}^{2}-c \mathrm{x}^{3}
$$

The parameters are defined here as in Eq. (3). All fitted regression parameters $\left(y_{0}, a\right.$, $b, c)$ describing $R$ as function of $t$ are compiled in Table 3. Average $R$ increased significantly from instar to instar (Fig. 2).

Table 3. Hyas araneus, larval instars. Fitted parameters $\left(y_{0}, a, b, c\right)$ and correlation coefficients (r) for regression equations (Eqs. 1 to 5; see text) describing changes during larval moult cycles (zoea I, zoea II, megalopa) in: feeding rate $(F)$, growth (dry weight, $W$; carbon, $C$; nitrogen, $N$; hydrogen, $H$; energy, E), respiration (R), and nitrogen excretion (U). All units the same as given in Table 2

\begin{tabular}{|c|c|c|c|c|c|c|c|c|c|}
\hline$y$ & & $F$ & $W$ & $C$ & $N$ & $H$ & $E$ & $R$ & $U$ \\
\hline \multirow{5}{*}{ Zoea I } & Yo & 12.1 & 59.2 & 21.7 & 5.39 & 3.25 & 0.76 & 0.182 & 4.73 \\
\hline & $a$ & 1.22 & 0.391 & 0.438 & 0.716 & 0.443 & 0.456 & 0.0182 & 1.916 \\
\hline & $b$ & -0.114 & & & & & & & -0.150 \\
\hline & $r$ & 0.922 & 0.996 & 0.982 & 0.992 & 0.973 & 0.965 & 0.993 & 0.820 \\
\hline & Eq. & 1 & 5 & 5 & 3 & 5 & 5 & 2 & 1 \\
\hline \multirow[t]{5}{*}{ Zoea II } & yo & 31.5 & 157.6 & 63.3 & 13.2 & 9.25 & 2.31 & 0.512 & 8.61 \\
\hline & $a$ & 0.81 & 0.269 & 0.287 & 0.232 & 0.294 & 0.295 & 0.0070 & 4.737 \\
\hline & $b$ & -0.194 & & & & & & & -0.365 \\
\hline & $r$ & 0.911 & 0.998 & 0.991 & 0.979 & 0.987 & 0.985 & 0.955 & 0.899 \\
\hline & Eq. & 1 & 5 & 5 & 5 & 5 & 5 & 3 & 1 \\
\hline \multirow[t]{6}{*}{ Megalopa } & $y_{0}$ & 25.4 & 369.0 & 141.2 & 27.6 & 19.4 & 5.08 & 0.869 & 20.31 \\
\hline & $a$ & -0.0496 & 36.5 & 13.5 & 2.19 & 2.26 & 0.47 & -0.0495 & 3.061 \\
\hline & $b$ & & -1.220 & -0.431 & -0.062 & -0.071 & -0.015 & 0.0065 & -0.114 \\
\hline & $c$ & & & & & & & 0.00017 & \\
\hline & $I$ & 0.940 & 0.869 & 0.938 & 0.982 & 0.914 & 0.924 & 0.930 & 0.696 \\
\hline & Eq. & 2 & 1 & 1 & 1 & 1 & 1 & 4 & 1 \\
\hline
\end{tabular}

Weight-specific respiration rate $\left(Q_{2} \mathrm{O}_{2}\right.$ dry weight-based) was maximum in early postmoult of each larval instar, and it was almost constantly low during the intermoult and premoult stages of the moult cycles (Fig. 2). On the average, there was a decreasing tendency in $\mathrm{QO}_{2}$ during development from the first to the last larval instar.

\section{Nitrogen excretion $(U)$}

Excretion rates (Table 2) increased during the initial phase of each moult cycle, reached maxima approximately in the early or intermediate premoult stages, then they decreased prior to ecdysis (Fig. 2). The average level of $U$ increased, as in $R$, from the first to the last larval instar. The variation patterns within the single moult cycles can be described by quadratic regression equations (type: Eq. 1). The fitted parameters are given in Table 3.

Weight-specific excretion rates (in $\mu \mathrm{g}$ ammonia nitrogen per mg dry weight) showed 
in principal similar patterns of variation as $U$, but with a slightly decreasing tendency from instar to instar (Fig. 2).

\section{Atomic $O / N$ ratio}

The patterns of change in the atomic $O / N$ ratio (Fig. 2) were dictated mainly by variations in $\mathrm{N}$-excretion. Maximum values were found shortly before and after each ecdysis, with the absolutely highest value (50) in freshly moulted zoea II larvae. Minimum values (ca 20 to 25 ) occurred during the intermoult and early premoult periods. The average level in $O / N$ showed a slightly decreasing tendency during development. The absolutely lowest value (15) was measured in freshly metamorphosed juvenile crabs (Fig. 2),

The atomic $\mathrm{O} / \mathrm{N}$ ratio indicates in all larval instars a mixed metabolic substrate, with a clear dominance of protein catabolism throughout major portions (intermoult, early premoult) of each moult cycle, and, increasingly, toward the end of larval development.

\section{Growth patterns}

The patterns of biomass increase (values measured in Experiment $A$ are given in Table 2) were mostly the same as in earlier investigations. Dry weight $(W)$, carbon (C), and nitrogen $(N)$ are shown as examples in Figure 3. Changes in $W, C, N, H$, and energy content (E) per individual were, in the zoeal instars, usually described by a power function (Anger \& Dawirs, 1982; Anger \& Jacobi, 1985):

$$
\mathrm{y}=\mathrm{y}_{0}(\mathrm{x}+1)^{\mathrm{a}}
$$

$y$ is here $W, C, N, H$, or $E_{;} x$ is time of development ( $t$, in days), and $y_{0}$ and $a$ are fitted constants. Reexamination of all complete data series available (see "Materials and Methods" section), however, revealed that the increase in $N$ during the zoea I instar follows in most of these cases a linear (Eq. 3) rather than a parabolic pattern (Eq. 5). This applies also to the data from Experiment $A$ (see Table 3).

Megalopa growth has been found in all previous studies on Hyas araneus larvae to follow a parabola shaped pattern (Fig. 3) that may be described by quadratic equations (Eq. 1; cf. Anger \& Dawirs, 1982; Anger \& Jacobi, 1985). The same pattern was found also in the present study (Experiment $A_{\text {; }}$ see Table 3 ).

Figure 3 shows the variation in larvae from different hatches studied during the past decade. It can be seen that the degree of variability increases during larval development, and it is in general greater in $W$ and $C$ than in $N$. The carbon content of intermoult megalopa originating from different hatches but reared under identical conditions (constant $12{ }^{\circ} \mathrm{C}$. Artemia nauplii fed ad libitum), for instance, may vary between ca 170 and $310 \mu \mathrm{g} \mathrm{ind}^{-1}$, i.e. by a factor of up to 1.8 . The data from the present study (Experiment $A_{;}$ Table 2) are found approximately in the middle of this range. Thus, they may be considered "representative" of larval growth in Hyas araneus, and the regression equations summarized in Table 3 can be used for modelling the partitioning of energy and matter during larval development. 


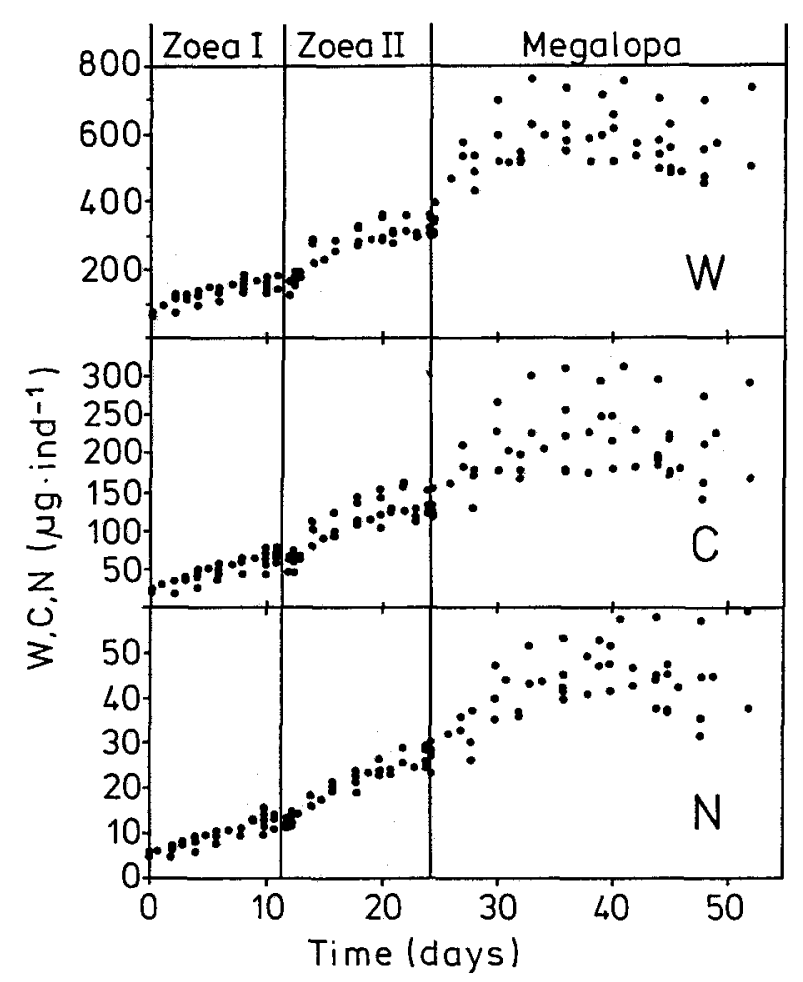

Fig. 3. Hyas araneus. Growth patterns during larval development (pooled data from the present and previous studies; see "Material and methods" for references); dry weight $(W)$, carbon $(C)$, and nitrogen $(N)$ shown as examples. Each data point represents a mean value from $12-13$ replicate analyses

\section{Elemental and biochemical composition}

Dry weight $(W)$ shows a particularly strong increase at the beginning of each moult cycle (Fig. 3). Since the organic constituents of $W$, i.e. $C, N, H$ do not increase as rapidly, their percentage values decrease during the postmoult stages ( $C$ and $N$ shown as examples in Fig. 4). This recurrent phenomenon indicates an initial phase of rapid uptake of inorganic substances. It is followed during intermoult and premoult by a period of true growth, i.e. accumulation of organic compounds.

The growth patterns differ somewhat between $C$ and $N$ : the former reaches a maximum and then remains rather constant throughout a major part of the moult cycle, whereas the latter reveals a practically continuous increase (Fig. 4). This difference is reflected also in the $C / N$ ratio. It shows in all larval instars a rapid initial increase, followed by rather constant or steadily decreasing values (Fig. 4). Since total growth does not cease before late premoult, decreasing $C / N$ ratios during the second half of the moult cycle do not indicate a reduction of $C$, but rather a proportionally faster accumulation of $N$ during this phase.

Figure 4 shows also the degree of variability in the percentage of $C, N$, and in their 
Physiology and biochemistry of crab larvae

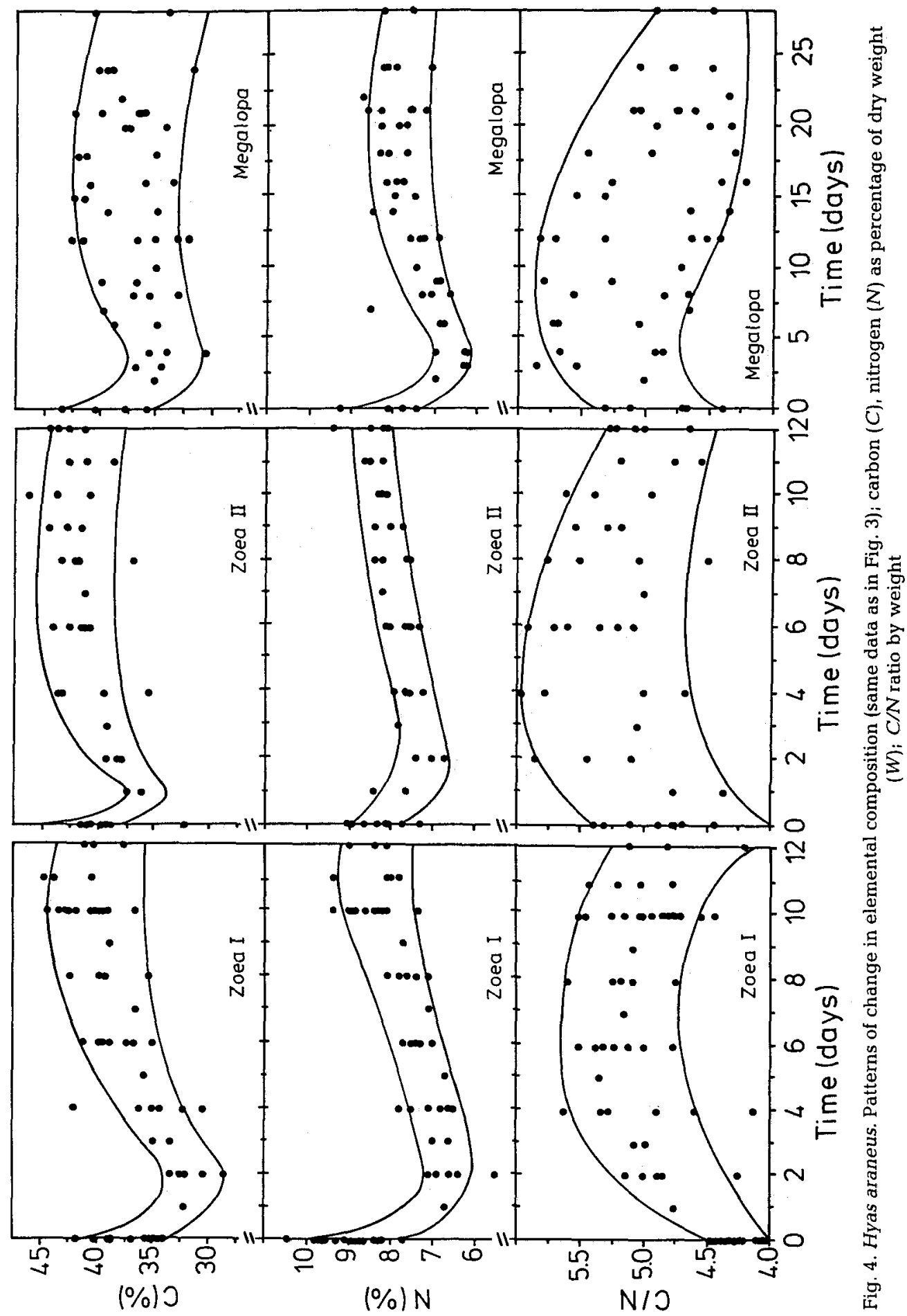


weight ratio. The curves are eye-fitted, depicting the typical patterns found in complete data series, one series with particularly high and another with very low biomass values. Again, the data from the present study (Experiment A) are intermediate in the range shown.

Variation in the percentage $C$ and the $C / N$ figures reflects mainly variation in the lipid content of larvae from different hatches, whereas changes in percentage $N$ values reflect protein variation. Figure 4 suggests that the degree of variability is in general greater in lipid than in protein, with particularly high variation in the megalopa instar. According to these patterns, the average level of lipid increases during the zoea I, reaches a maximum in the zoea $\mathrm{II}$, and eventually decreases during megalopa development.

These indirectly measured patterns of variation in proximate biochemical composition during larval development of Hyas araneus are confirmed by direct measurements (Fig. 5). Lipid, however, was measured only in Experiment B. These values show that $H$. araneus larvae contain in general much more protein than lipid. Since variation between different hatches in the percentage of protein (Fig. 5) does not correspond to an equal variability in the absolute (per individual) values of this component, lipid should be the main source of variation in the relative (\% of $W$ ) biochemical composition of larvae from different hatches. Comparatively low percentage protein values in Experiment B (Fig. 5 , middle graph) suggest that both the percentage lipid and the lipid/protein ratio may be normally lower than found in this hatch. As in elemental composition, the hatch used in Experiment A appears to represent average ("typical") figures to be expected in $H$. araneus larvae.

While there is a continuous increase in the absolute values of both lipid and protein from hatching to the middle of megalopa development, the ultimate larval instar reveals decreasing biomass during the second part of its moult cycle (see above). This decrease is mainly found in the lipid fraction, whereas the amounts of protein per individual remain rather constant during this final period of larval development (Fig. 6). As a consequence, the lipid/protein ratio shows a conspicuous decrease during this phase (Fig. 5).

\section{Interrelationships between different measures of biomass}

The great amount of data collected during the past decade allows us to quantify some statistical relationships between total dry weight $(W)$ and different chemical compounds that are also used as measures of biomass. When data from complete larval development are pooled, $C, N$, and $H$ appear to show linear relationships with $W$ (Fig. $7 ; C$ shown as an example). A closer analysis of the data, however, reveals that the non-linear growth patterns during individual moult cycles (see above) complicate that prediction of elemental constituents from $W$. The linear regression given in Figure 7 (upper left graph) therefore yields only a rough estimate, as it assumes an almost constant percentage of $C$. Actual variation in the percentage of $C$ (Fig. 4) is reflected in exponential regression curves computed separately for each larval instar (Fig. 7).

$C$ shows highly significant correlations with both $N$ and $H$ (Fig. 8). The particularly high correlation between $C$ and $H$ shows a rather constant $C / H$ ratio, whereas the $C / N$ ratio may vary considerably, due to variation in the protein content (see above).

$C$ and $N$ are good predictors also of total lipid and protein, respectively (Fig. 9). In 
Physiology and biochemistry of crab larvae

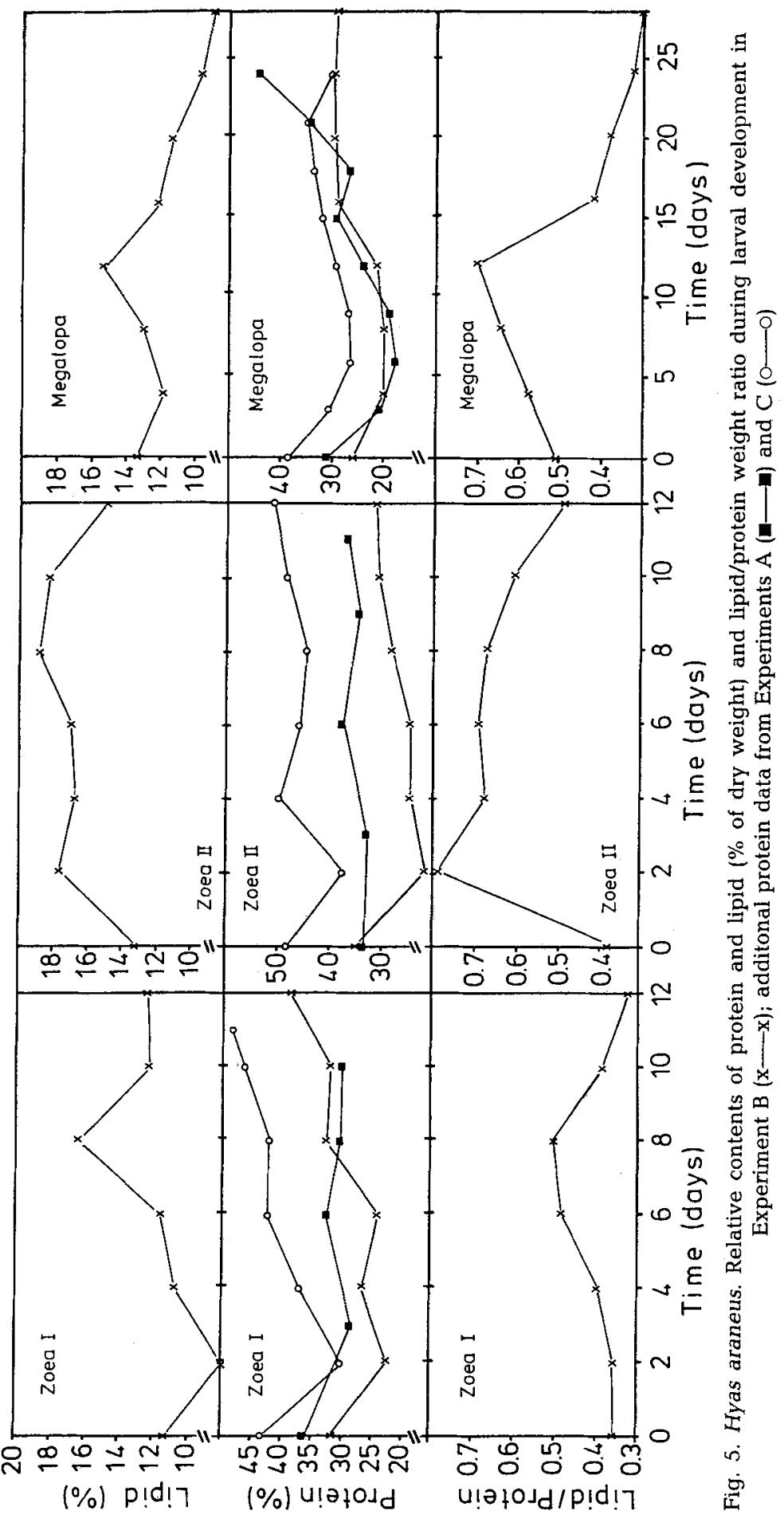


K. Anger, J. Harms, C. Püschel \& B. Seeger

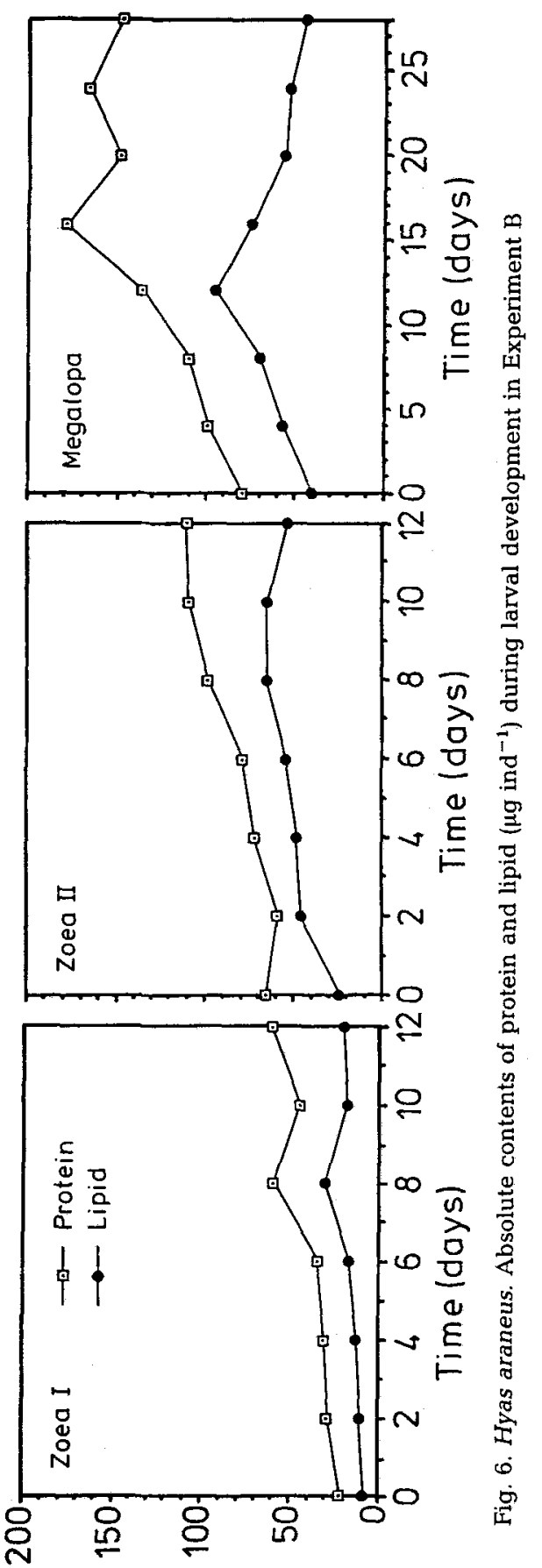

(l-pu! $6 n$ )

p!d! ' Uiptodd 

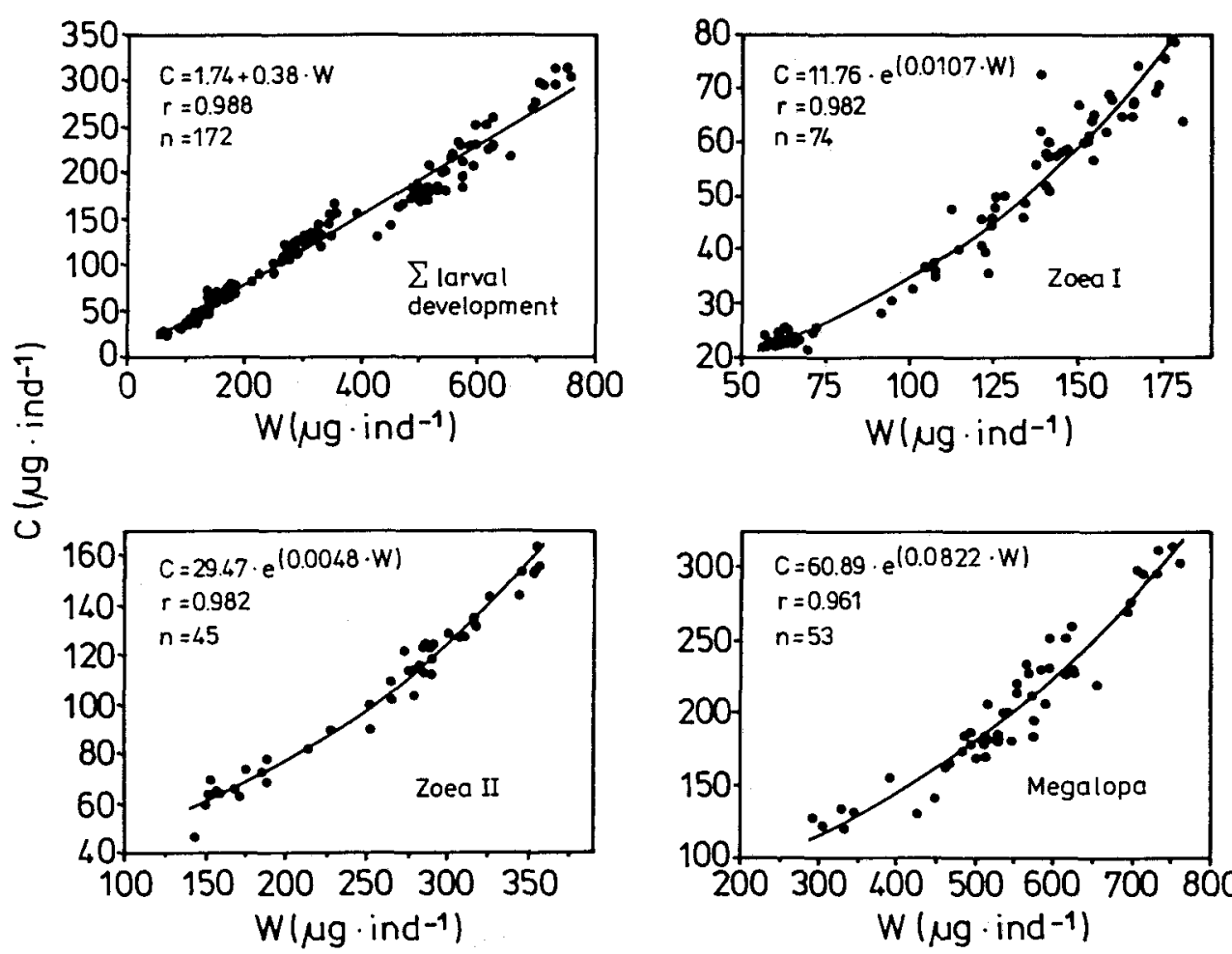

Fig. 7. Hyas araneus. Relationship between dry weight $(W)$ and carbon $(C)$ in the individual larval

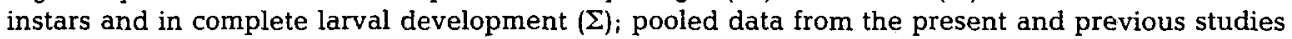
(see "Material and methods" for references); $r, n$ : correlation coefficient, number of mean values (from 12-13 replicate analyses eaçh)

both cases, a non-linear (power function) model gave a better fit between predicted and observed data than a linear model.

\section{DISCUSSION}

The present study provides the data base for budgets of energy, carbon, and nitrogen, and it has scrutinized previous results on physiological and biochemical changes during larval development of Hyas araneus.

The uptake of energy and matter $(F)$ had been measured already by Anger \& Dietrich (1984). The present study, however, yielded more reliable data, since more replicate experiments were carried out (20 vs 10 ), and larval development duration in the experiments was shorter, probably due to better viability of larvae, or slightly improved experimental conditions (the test vials had the same volume but a higher bottom surface : height ratio than in previous experiments). The patterns of variation in the ingestion rate of zoea larvae were in these two studies basically the same: $F$ followed a bell-shaped curve, with a maximum in the middle (zoea I) or in the first part (zoea II) of the moult cycle. The megalopa showed in general a decreasing $F$ during its moult cycle, with a 


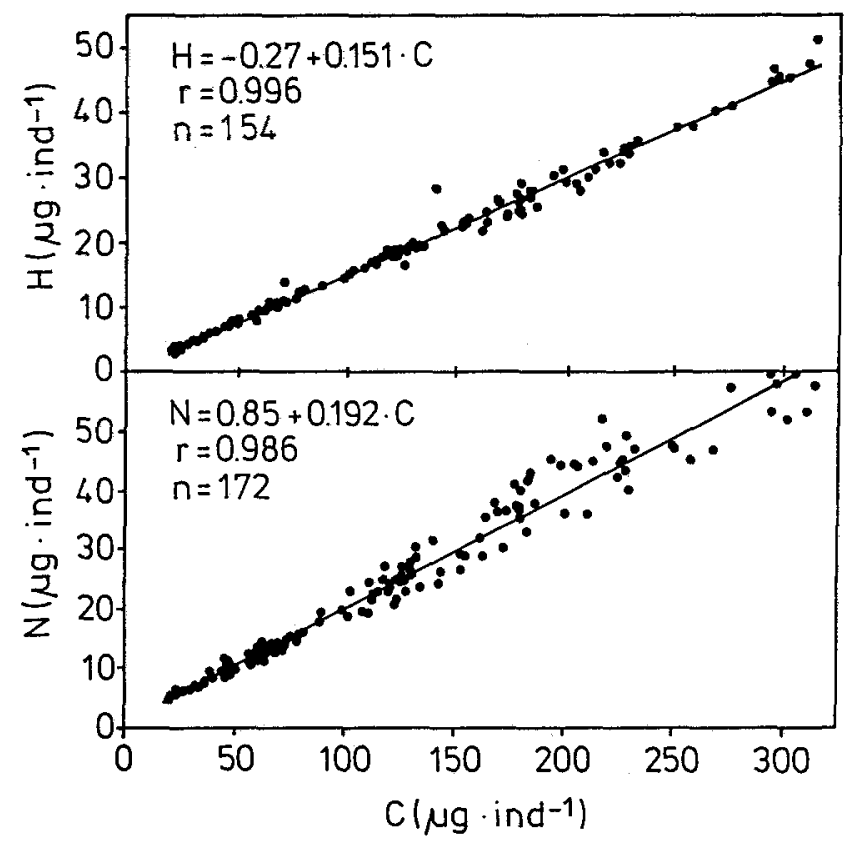

Fig. 8. Hyas araneus. Relationships between carbon $(C)$, nitrogen $(N)$, hydrogen $(H)$ in larvae and early juveniles; pooled data from the present and previous studies (see "Material and methods" for references); $r, n$ : as in Figure 7

much clearer tendency in the present study (Fig. 1). In a comparable investigation on ingestion rates of shore crab (Carcinus maenas) larvae, Dawirs \& Dietrich (1986) found also consistently decreasing $F$ values during the moult cycles of late instars (zoea IV, megalopa), whereas earlier instars revealed variable patterns modified by temperature.

In all of these studies, high individual and moult cycle-related variability was observed in larval feeding rates. Hence, the use of single "representative" measurements taken from an unspecified stage of the moult cycle may yield an unrealistic estimate of average $F$ in a given instar. Such simplistic approach may seriously affect the reliability of bioenergetic comparisons, e.g. between distinct larval instars or species, and thus, the comparability of literature data. Also the present $F$ values are not fully compatible with the rest of the data (respiration, excretion, growth), because they were measured in larvae originating from a different hatch (Experiment B). Since growth was checked in both experiments (A and $B$ ) and found to be similar, the combination of these data appears justified.

Respiration rate $(R)$ showed the same patterns of variation during individual moult cycles as observed in previous studies on Hyas araneus (Anger \& Jacobi, 1985) and $H$. coarctatus (Jacobi \& Anger, 1985): linear increase in each zoeal instar, with a weaker slope in the zoea II, and a sinusoidal pattern in the megalopa (Fig. 2). This correspondence of results obtained in independent studies suggests that these patterns might be general in brachyuran or at least majid larvae, however, too little information from 


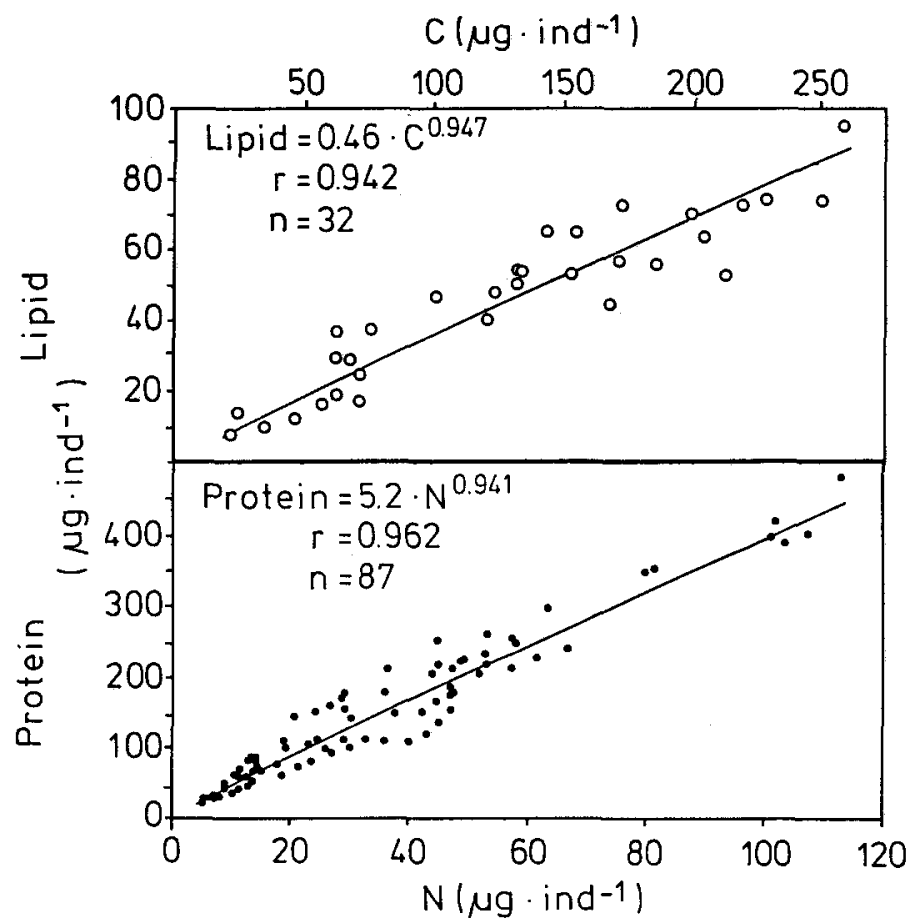

Fig. 9. Hyas araneus. Relationships between carbon $(C)$ and lipid, and between nitrogen $(N)$ and protein in larvae and early juveniles; pooled data from the present and previous studies (see "Material and methods" for references); $r$, n: as in Figure 7

different taxa is available at present to allow generalizations. Moreover, such patterns may be modified by temperature (Anger, 1987) or other external factors.

Weight-specific respiration $\left(\mathrm{QO}_{2}\right)$ was in all larval instars of $H$. araneus maximum in early postmoult, followed by constantly low values (Fig. 2). It decreased, on the average, from the first to the last instar. The same patterns had been found before in Hyas spp. (Anger \& Jacobi, 1985; Jacobi \& Anger, 1985). Sasaki et al. (1986) found a similar variation pattern in $\mathrm{QO}_{2}$ during the moult cycles of larval lobsters (Homarus americanus), but they measured increasing average levels from the first to the last (third) instar. The latter finding is surprising, as there is normally a negative correlation between $Q_{2}$ and weight (e.g. Zeuthen, 1953). Dawirs (1983) observed also a positive relationship between $\mathrm{QO}_{2}$ and $\mathrm{W}$ in Carcinus maenas larvae exposed to high temperature $\left(25^{\circ} \mathrm{C}\right)$, whereas at lower temperatures $\left(12^{\circ} \mathrm{C}, 18^{\circ} \mathrm{C}\right)$ negative slopes were found.

Nitrogen excretion $(U)$ followed in all larval instars a parabola-shaped pattern, with a maximum in the middle of the moult cycle or somewhat later (Fig. 2). The same applies to weight-specific excretion rate $(U / W)$. The only comparable data available from other decapod larvae (Sasaki et al, 1986) show an opposite tendency. The average level of $U / W$ measured in Hyas araneus was lower than most values given by other authors (Logan \& Epifanio, 1978; Capuzzo \& Lancaster, 1979; Johns, 1982; Sasaki et al., 1986). This difference may have been caused by relatively long incubation time in our experi- 
ments ( $15 \mathrm{~h}$ vs $3-5 \mathrm{~h}$ ), as lack of food during this period may reduce excretion compared to that in freshly fed larvae (Capuzzo \& Lancaster, 1979).

The atomic $O / N$ ratio is considered an indicator of the metabolic substrate. The average level is in Hyas araneus larvae (Fig. 2) similar to that in larval lobsters (Capuzzo \& Lancaster, 1979; Sasaki et al. 1986) and crabs (Johns, 1982), showing a predominantly protein-based metabolism. As in lobsters, the average $O / N$ showed a slightly decreasing tendency during larval development, indicating an increasing significance of protein catabolism in later developmental instars.

The larval growth patterns observed in the three experiments $(A-C)$ of the present study agree well with those in previous investigations on decapod larvae: Hyas araneus (Anger \& Dawirs, 1982; Anger \& Jacobi, 1985), H. coarctatus (Jacobi \& Anger, 1985), Carcinus maenas (Dawirs, 1983; Dawirs et al., 1986), Nephrops norvegicus (Anger \& Püschel, 1986), Inachus dorsettensis (Anger, 1988). The present review of growth data measured in $H$. araneus larvae shows that there is quite a lot of variability between different hatches (Fig. 3), however, with rather constant patterns of variation during individual larval moult cycles. The great variability in the absolute (e.g. $\mu \mathrm{g} \mathrm{Cind}^{-1}$ ) values of different hatches shows again that parallel bioenergetic measurements (e.g. of growth and respiration) should be carried out, if possible, with larvae from the same hatch.

Relative composition (\% $W$ ) of Hyas araneus larvae varies considerably during individual moult cycles (Figs 4,5). During and after ecdysis, the larvae take up great amounts of water (Anger \& Dawirs, 1982) and, thus, inorganic substances. This leads to a conspicuous transient decrease in the percentages of organic constituents $(C, N, H$, protein, lipid) during the postmoult stages of the moult cycle, although the absolute amounts (in $\mu \mathrm{g} \mathrm{ind}^{-1}$ ) of these constituents increase (Figs 3,6 ). This increase is initially stronger in $C$ and lipid than in $N$ and protein (Figs 4,5). Lipid accumulation takes place mainly in the R-cells of the larval hepatopancreas (Storch \& Anger, 1983). Later in the moult cycle, the larvae accumulate proportionally more protein than lipid, and the $C / N$ ratio decreases. This is caused by epidermal growth associated with morphogenesis during the premoult stages of the moult cycle (Anger, 1983). The same patterns were found also in detailed studies by Dawirs (1983) and Dawirs et al. (1986) on Carcinus maenas, and in further investigations on decapod larvae: Hyas coarctatus (Jacobi \& Anger, 1985), Nephrops norvegicus (Anger \& Püschel, 1986), Inachus dorsettensis (Anger, 1988). This correspondence suggests that these patterns of biochemical change during individual moult cycles may be general in planktotrophic decapod larvae.

Besides moult cycle-related changes, there are differences in the average biochemical composition of different larval instars (Figs 4,5). There is a clear increase in the percentage of lipid throughout zoeal development, whereas the megalopa reveals an increase only during the first half of its moult cycle, and a decrease in the second half. Protein, in contrast, is accumulated during almost the entire course of larval development. These differences may reflect differences in the ecological "roles" of subsequent larval instars within the life cycle of a crab: the zoeal instars behave like holoplanktonic animals (with the exception of lacking reproduction), accumulating energy and matter and investing it mainly in body growth. The late megalopa, in contrast, undergoes significant behavioural and anatomical changes that eventually lead to settling and metamorphosis. The transition from the pelagic to the benthic environment is accompanied by energy consuming processes such as the search for a suitable habitat and 
internal reconstruction processes, while feeding activity is simultaneously reduced (Fig. 1; cf. Anger \& Dietrich, 1984; Dawirs \& Dietrich, 1986). Apparently, in the premetamorphic phase priority is given to habitat selection over search for food. Energy partitioning then shifts from a quantitative (accumulation) growth strategy to a qualitative strategy: the utilization of reserves for epidermal reconstruction (morphogenesis). Further increasing amounts of protein during the megalopa moult cycle (Fig. 6) show that morphogenesis proceeds in the epidermis, while decreasing lipid figures indicate the use of fat reserves from the hepatopancreas.

It should be expected that the bioenergetic traits of the juvenile crab are similar to those in the zoeal instars: quantitative growth should again have priority over morphogenesis. This assumption, however, remains to be tested in future experiments.

The non-linear relationships between dry weight $(W)$ and other measures of larval biomass (Fig. 7) reflect developmental changes in biochemical composition as discussed above. Further quantitative interrelations between different measures of biomass (Figs 8 , 9) have now been established on a broad basis of analytical data, and they will in future help to estimate one chemical component from another, when not so many parallel analyses are possible. Comparative studies with a number of further decapod species are being conducted, in order to allow a wider application of such empirical conversion models. They may become useful for estimates of production of decapod larvae in the planktonic environment (Lindley, 1988).

Hyas araneus has become a suitable standard model system for the study of physiological and biochemical changes during larval development of a brachyuran that will help to interpret future results obtained from other decapod crustaceans. Besides comparative studies, future work will include to a greater extent the modification of internal (developmental) changes by external (ecological) factors, and laboratory data will have to be compared with those to be obtained in the field.

Acknowledgements. Our investigations on the bioenergetics of decapod larvae have been generously supported by the Deutsche Forschungsgemeinschaft (DFG; grants under "An/145"). The first author acknowledges technical assistance by Mrs B. Köhn, who also made the line drawings.

\section{LITERATURE CITED}

Anger, K, 1983. Moult cycle and morphogenesis in Hyas araneus larvae (Decapoda, Majidae), reared in the laboratory. - Helgoländer Meeresunters. 36, 285-302.

Anger, K., 1987. Energetics of spider crab Hyas araneus megalopa in relation to temperature and the moult cycle. - Mar. Ecol. Prog. Ser. 36, 115-122.

Anger, K., 1988. Growth and elemental composition (C, N, H) in Inachus dorsettensis (Decapoda: Majidae) larvae reared in the laboratory. - Mar. Biol. 99, 255-260.

Anger, K. \& Dawirs, R. R., 1982. Elemental composition (C, N, $H$ ) and energy in growing and starving larvae of Hyas araneus (Decapoda, Majidae). - Fish. Bull. U.S. 80, 419-433.

Anger, K. \& Dietrich, A., 1984. Feeding rates and gross growth efficiencies in Hyas araneus L. larvae (Decapoda: Majidae). - J. exp. mar. Biol. Ecol. 77, 169-191.

Anger, K. \& Jacobi, C. C., 1985. Respiration and growth of Hyas araneus L. larvae (Decapoda: Majidae) from hatching to metamorphosis. - J. exp. mar. Biol. Ecol. 88, 257-270.

Anger, K. \& Püschel, C., 1986. Growth and exuviation of Norway lobster (Nephrops norvegicus) larvae reared in the laboratory. - Ophelia 25, 157-167.

Anger, K., Laasch, N., Püschel, C. \& Schorn, F., 1983. Changes in biomass and chemical composition of spider crab (Hyas araneus) larvae reared in the laboratory. - Mar. Ecol. Prog. Ser. 12, 91-101. 
Capuzzo, J. M. \& Lancaster, B. A., 1979. Some physiological and biochemical considerations of larval development in the American lobster, Homarus americanus Milne Edwards. - J. exp. mar. Biol. Ecol. 40,53-62.

Dawirs, R. R, 1983, Respiration, energy balance and development during growth and starvation of Carcinus maenas L. larvae (Decapoda: Portunidae). - J. exp. mar. Biol. Ecol. 69, 105-128.

Dawirs, R. R. \& Dietrich, A., 1986. Temperature and laboratory feeding rates in Carcinus maenas L. (Decapoda: Portunidae) larvae from hatching through metamorphosis. - J. exp. mar. Biol. Ecol. 99, 133-147.

Dawirs, R. R., Püschel, C. \& Schorn, F., 1986. Temperature and growth in Carcinus maenas L. (Decapoda: Portunidae) larvae reared in the laboratory from hatching through metamorphosis. J. exp. mar, Biol. Ecol. 100, 47-74.

Drach, P., 1939. Mue et cycle d'intermue chez les Crustacés décapodes. - Annls Inst. océanogr., Monaco 19, 103-391.

Emmerson, W. D., 1980. Ingestion, growth and development of Penaeus indicus larvae as a function of Thalassiosira weissflogii cell concentration. - Mar. Biol. 58, 65-73.

Grasshoff, K., 1976. Methods of sea water analysis. Verl. Chemie, Weinheim, 317 pp.

Hirche, H.-J. \& Anger, K. 1987a. Digestive enzyme activities during larval development of Hyas araneus (Decapoda, Majidae). - Comp. Biochem. Physiol. 87 B, 297-302.

Hirche, H.-J. \& Anger, K., $1987 \mathrm{~b}$. The accumulation of age pigments during larval development of the spider crab, Hyas araneus (Decapoda, Majidae). - Comp. Biochem. Physiol. 88 B, 777-782.

Jacobi, C. C. \& Anger, K., 1985. Growth and respiration during the larval development of Hyas coarctatus (Decapoda: Majidae). - Mar. Biol. 87, 173-180.

Johns, D. M., 1982. Physiological studies on Cancer irroratus larvae. III. Effects of temperature and salinity on the partitioning of energy resources during development. - Mar. Ecol. Prog. Ser. 8, 75-85.

Kunisch, M. \& Anger, K., 1984. Variation in development and growth rates of larval and juvenile spider crabs Hyas araneus reared in the laboratory. - Mar. Ecol. Prog. Ser. 15, 293-301.

Levine, D. M. \& Sulkin, S. D., 1979. Partitioning and utilization of energy during the larval development of the xanthid crab, Rhithropanopeus harrisii (Gould). - J. exp. mar. Biol. Ecol. 40, $247-257$.

Lindley, J. A., 1988. Estimating biomass and production of pelagic larvae of brachyuran decapods in western European shelf waters. - J, exp. mar. Biol. Ecol. 122, 195-211.

Logan, D. T. \& Epifanio, C. E., 1978. A laboratory energy balance for the larvae and juveniles of the American lobster Homarus americanus. - Mar. Biol. 47, 381-389.

Lowry, D. H., Rosenberg, N. J., Farr, A. L. \& Randall, R. J., 1951. Protein measurement with the folin phenol reagent. - J. biol. Chem. 193, 265-275.

Mootz, C. A. \& Epifanio, C. E., 1974. An energy budget for Menippe mercenaria larvae fed Artemia nauplii. - Biol. Bull. mar. biol. Lab., Woods Hole 146, 44-55.

Paul, A. J. \& Nunes, P., 1983. Temperature modification of respiratory metabolism and caloric intake of Pandalus borealis (Krøyer) first zoeae. - J. exp. mar. Biol. Ecol. 66, 163-168.

Salonen, K., Sarvala, J., Hakala, I. \& Viljanen, M.-L., 1976. The relation of energy and organic carbon in aquatic invertebrates. - Limnol. Oceanogr. 21, 724-730.

Sasaki, G. C., Capuzzo, J."M. \& Biesiot, P., 1986. Nutritional and bioenergetic considerations in the development of the American lobster Homarus americanus - Can. J. Fish. aquat. Sci. 43, 2311-2319.

Solorzano, L., 1969. Determination of ammonia in natural waters by the phenolhypochlorite method. - Limnol. Oceanogr. 14, 799-801.

Spindler, K.-D. \& Anger, K., 1986. Ecdysteroid levels during the larval development of the spider crab Hyas araneus. - Gen. comp. Endocrinol. 64, 122-128.

Storch, V. \& Anger, K., 1983. Influence of starvation and feeding on the hepatopancreas of larval Hyas araneus (Decapoda, Majidae). - Helgoländer Meeresunters. 36, 67-75.

Zeuthen, E., 1953. Oxygen uptake as related to body size in organisms. - Q. Rev. Biol. 28; 1-12.

Zöllner, N. \& Kirsch, K., 1962. Über die quantitative Bestimmung von Lipoiden (Mikromethode) mittels der vielen natürlichen Lipoiden (allen bekannten Plasmalipoiden) gemeinsamen Sulfophosphovanillin-Reaktion. - Z. ges. exp. Med. 135, 545-561. 